\title{
Select the Sex of Your Next Calf Prior to Mating: Using Sexed Semen 1
}

Gary R. Hansen ${ }^{2}$

\section{Introduction}

Through recent advances in reproductive technology, scientists have the ability to pre-select the sex of mammalian offspring prior to mating. This is accomplished through a procedure known as flow cytometry cell sorting where $\mathrm{X}$ - (female) or $\mathrm{Y}$-(male)-chromosome-bearing cells are sorted based on DNA content of the sperm cell.

Flow cytometry (measurement of cells as they flow by a detector) has been available for analysis and sorting a variety of cell types in fluid suspension since the late 1970s. Flow cytometers (Figure 1) use focused laser light to illuminate cells as they pass the laser beam, one at a time, in a fine fluid stream. Light scattered by the cells and light emitted by fluorescent dyes attached to cells of interest are analyzed by several detectors and processed by a computer. Cells may be distinguished and selected on the basis of size and shape as well as by the presence of many different molecules inside and on the surface of the cells.

\section{Sorting Sperm Cells}

In a normal male ejaculate, half of the sperm cells contain an $\mathrm{X}$ chromosome which results in a female upon fertilization, while the other half contain a Y chromosome resulting in a male. Sperm cells bearing the $\mathrm{X}$ chromosome contain $\sim 4 \%$ more DNA than Y-chromosome-bearing cells. Staining procedures allow for identification of $\mathrm{X}$ - and $\mathrm{Y}$ chromosome-bearing cells. Sperm cells are exposed to DNA binding stain for about 45 minutes. Following staining, sperm cells enter the flow cytometer where a vibrating peizo electric crystal separates each cell into a single droplet (Figures 1 and 2 ). The droplets then pass through the laser beam in single file. The cells fluoresce at different intensities when exposed to a specific wave length of blue light (Figure 3). Cells with greater fluorescence would be $\mathrm{X}$-chromosome-bearing because more stain would be incorporated into a cell with greater quantities of DNA available for binding. After chromosome content is determined, either a negative or positive charge is applied to each sperm cell. Sorting can then take place as the sperm cells are attracted to either the positive or negative plate depending on which charge was previously applied (Figure 4).

1. This document is AN163, one of a series of the Animal Sciences Department, Florida Cooperative Extension Service, Institute of Food and Agricultural Sciences, University of Florida. Original publication date April, 2006. Visit the EDIS Web Site at http://edis.ifas.ufl.edu.

2. Hansen, G.R., Assistant Professor of Animal Science, North Florida Research and Education Center Marianna, Cooperative Extension Service, Institute of Food and Agricultural Sciences, University of Florida, Gainesville, 32611.

The Institute of Food and Agricultural Sciences (IFAS) is an Equal Opportunity Institution authorized to provide research, educational information and other services only to individuals and institutions that function with non-discrimination with respect to race, creed, color, religion, age, disability, sex, sexual orientation, marital status, national origin, political opinions or affiliations. U.S. Department of Agriculture, Cooperative Extension Service, University of Florida, IFAS, Florida A. \& M. University Cooperative Extension Program, and Boards of County Commissioners Cooperating. Larry Arrington, Dean 


\section{Economic Implications}

Sorted sperm cells have resulted in pregnancies in several species including cattle, horses, sheep, swine, dogs, baboons and humans. Pre-selecting the sex of animals used for production agriculture is particularly valuable in instances where one sex is more valuable in the production chain. For example, in commercial dairy operations with the exception of a few bull calves produced from the very top cows, male calves have little value. On the other hand, the value of heifer calves is at a premium. The opposite is true in commercial beef cattle production. Sperm cell sorting would allow commercial beef producers to select semen that when used that would produce the desired sex in a majority of the animals. This technology would also benefit producers using crossbreeding systems that employ maternal (F-1 cows) and/or terminal cross lines because only a minimum number of cows would be needed to produce crossbred replacements or slaughter animals depending on production goals. Research shows F-1 Bos taurus X Bos indicus females as the most productive in the Gulf Coast region of the United States. One of the major deterrents to producing Bos taurus X Bos indicus replacement females is how to successfully market the male counterparts. Sexed semen would not only reduce the number of purebred cows needed to produce the heifers, but very few males would be produced almost eliminating the need to market this class of animal. Purebred breeders often prefer certain cows to produce a heifer or bull calf depending on previous matings. Flow cytometry/cell sorting results in approximate $90 \%$ accuracy of pre-selected-sex calves.

Some risk is assumed with all technologies that manipulate components of the reproductive system. Studies to date have shown no significant difference in production characteristics of calves produced from flow cytometry/cell sorting versus calves produced conventionally.

\section{Challenges}

Adoption of this new technology will depend on whether producers can economically justify the cost to process the sexed semen. Recent advancements have overcome some of the problems involved with flow cytometry/cell sorting. Sorting rate has been a problem, especially in species that require a large number of viable sperm cells to be present for fertilization to take place. New procedures have decreased sorting time by four times, however these rates only allow 6 to 10 straws of semen to be sorted per hour. Deep uterine insemination has lead to a decrease in the number of sperm cells required ( 2 million versus 15 to 30 million) when inseminating bovine females with sorted semen, allowing for more straws to be processed per hour.

Recently, frozen sexed bovine semen has resulted in pregnancies, which allows more flexibility in shipping and storage. Previously, only fresh semen had been used, limiting insemination to females close to the semen collection facility. Researchers at Colorado State University have been able to achieve pregnancy rates that are 70 to $80 \%$ of normal rates when using low dose insemination (Table 1). Heifers were inseminated with fresh and frozen sexed semen along with conventional frozen semen. Although pregnancy rates were lower for heifers inseminated with sexed semen, the cells/dose was dramatically reduced as well. Results will continue to improve as new methods and techniques are implemented when using sexed semen. Select Sires has conducted extensive field trials using sexed semen. Over 2,249 services in 40 herds were performed using 3 sires which resulted in almost identical results (Table 2).

Artificial insemination organizations are selling sexed semen to livestock producers on a commercial basis. The cost of sexed semen ranges from $\$ 32$ to $\$ 50$ USD for proven dairy bulls, while the price is highly variable for beef bulls.

\section{Using Sexed Semen}

Using sexed semen requires a breeding gun that will hold 1/4-cc straws. Straws are thawed and handled using the same procedures as $1 / 2$-cc straws. Decreased straw diameter and number of cells/dose make them more sensitive to cold shock and technician errors. Using the guidelines below will increase the probability for success:

- Insure that semen is stored at proper temperatures. 
- Thaw straws according to procedures recommended by the AI stud that processed the semen. Usually $95^{\circ} \mathrm{F}$ water bath for 45 seconds.

- Insure that AI equipment is clean and sanitary.

- Warm equipment (sheaths, guns, paper towels, etc.) prior to contact with semen. Insure straws are maintained at proper temperatures while being handled.

- Avoid exposing semen to direct sunlight or water.

- Do not use lulubricants that are spermicidal.

- Use highly qualified technicians when using sexed semen.

- Insure animals are in good body condition score and are cycling.

- Inseminate cattle twelve hours (AM/PM rule) after observed estrus.

- Breed only those animals that display heat if using an estrus synchronization protocol.

More information concerning the production of mammalian offspring using sex sorted semen is available at http://www.xyinc.com.

\section{Figure 1 Diagram}

1. Sperm cells stained with fluorescent dye enter sorter:

2. A piezo electric crystal undulates, which breaks the stream into $\sim 90,000$ droplets/second:

3. A laser beams blue light on sperm cells:

4. X-chromosome-bearing sperm cells fluoresce with $4 \%$ more intensity than Y-chromosome-bearing sperm:

5. A computer processes the fluorescence detected and categorizes the sperm as $\mathrm{X}, \mathrm{Y}$ or uncertain:

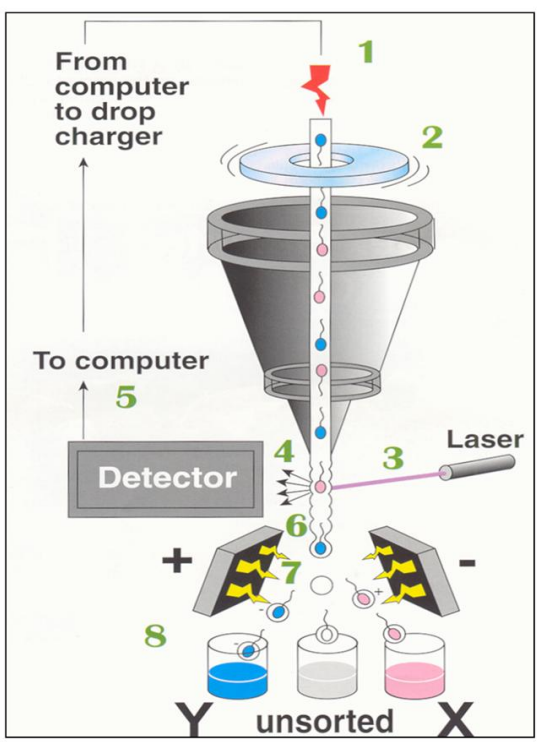

Figure 1. Diagram illustrating sperm sexing procedures using a flow cytometer/cell sorter to measure DNA content. Credits: Adapted from Embryo Transfer in Dairy Cattle Copyright by W. D Hoards and \& Sons Company (used by permission).

6. Negative, positive or no charge is applied to droplets depending on sex:

7. The charged droplets are deflected as they pass between continuously charged plates:

8. Samples are collected in three containers, $\mathrm{X}$ \& Y-chromosome-bearing and unsorted.

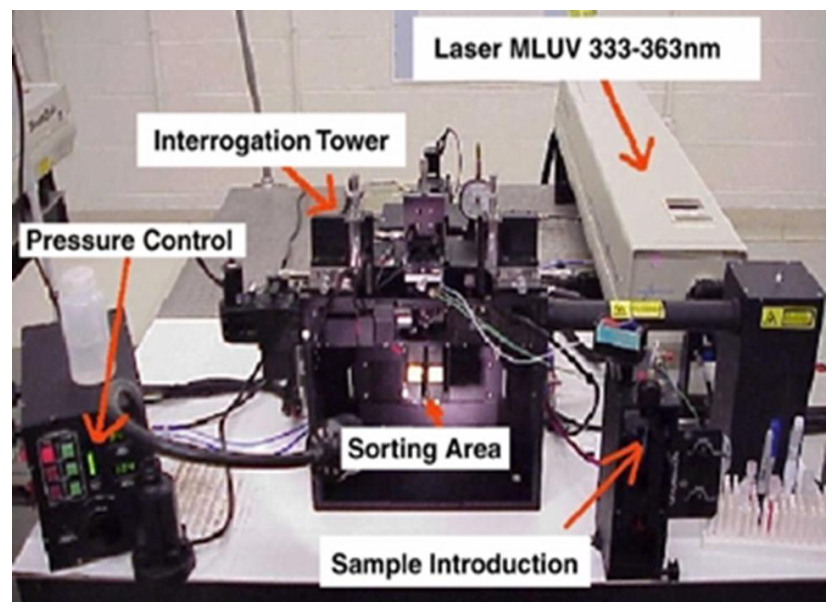

Figure 2. MoFlo ${ }^{\circledR}$ flow cytometer/cell sorter 


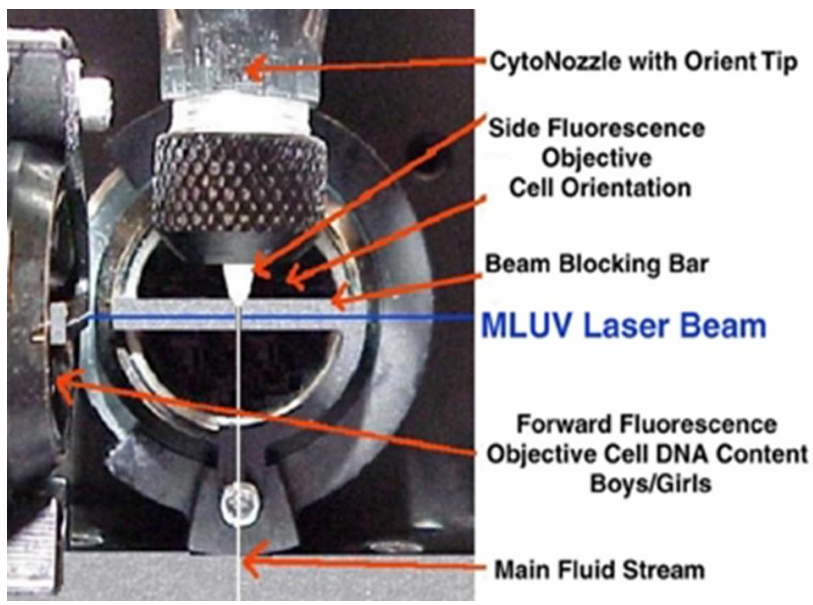

Figure 3. Close up of interrogation tower

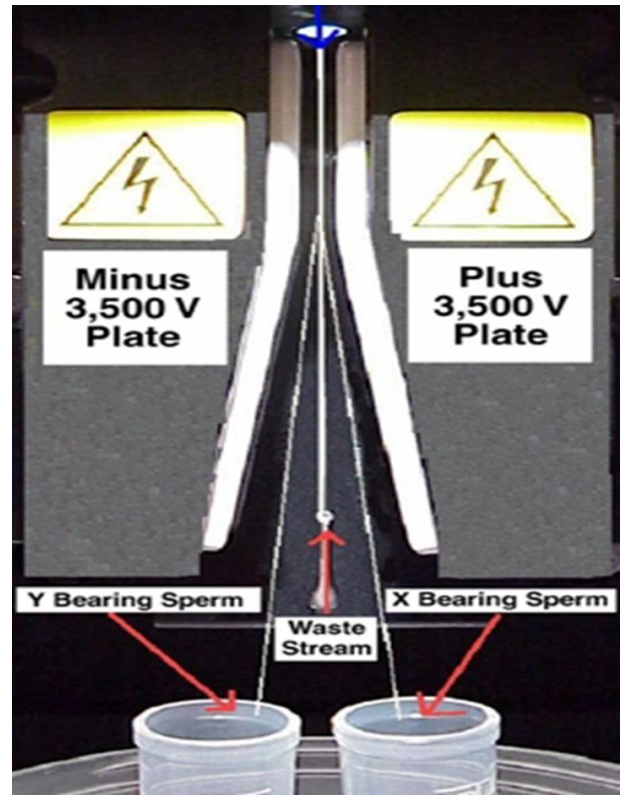

Figure 4. Continuously charged electric plates. 
Table 1. Pregnancy rates in heifers inseminated with low dose fresh or frozen sexed semen and conventional frozen semen.

\begin{tabular}{||l|c|c|c|c||}
\hline \hline & No. of Heifers & Cells/dose & $\%$ pregnant & $\%$ female \\
\hline Sexed liquid semen & 37 & .5 Million & $30 \%$ & $100 \%$ \\
\hline Sexed frozen semen & 35 & 1 Million & $51 \%$ & $94 \%$ \\
\hline Frozen control semen & 37 & 40 Million & $73 \%$ & $59 \%$ \\
\hline \hline
\end{tabular}

Table 2. Conception rates using sexed semen for 3 Holstein sires.

\begin{tabular}{||l|c|c||}
\hline \hline Sire ID & Number of Services & Conception rate \\
\hline 7HO6329 & 645 & 42 \\
\hline 7HO6454 & 730 & 45 \\
\hline 7HO6685 & 874 & 46 \\
\hline Non-Sexed & --- & 61 \\
\hline \hline
\end{tabular}

